Edunomika - Vol. 03, No. 01 (Februari 2019)

\title{
ANALISA KINERJA KEUANGAN PADA KOPERASI PEGAWAI REPUBLIK INDONESIA KANTOR URUSAN AGAMA KABUPATEN WONOGIRI PERIODE 2014-2017
}

\author{
Sri Lestari, Burhanudin AY, Ida Aryati Diyah Purnomo Wulan \\ Islam Batik University of Surakarta, Indonesia \\ Email : srilestari11@gmail.com
}

\begin{abstract}
The research aims to find out and describe finance performance in Koperasi Pegawai Republik Indonesia Kantor Urusan Agama Kabupaten Wonogiri period 2014-2017. This research using quantitative descriptive research. The data used in this research is secondary data are derived from the financial statements Koperasi Pegawai Republik Indonesia Kantor Urusan Agama Kabupaten Wonogiri period 2014-2017. Data analysis technique used was fiancial ratio analysis. The result show that finance performance in Koperasi Pegawai Republik Indonesia Kantor Urusan Agama Kabupaten Wonogiri period 2014-2017 based on the ratio of earning indicate the cooperatives are in less good condition. Finance performance in Koperasi Pegawai Republik Indonesia Kantor Urusan Agama Kabupaten Wonogiri period 20142017 based on the ratio of activities shows the cooperative is in bad condition. Finance performance in Koperasi Pegawai Republik Indonesia Kantor Urusan Agama Kabupaten Wonogiri period 2014-2017 based on liquidity ratios indicate the cooperatives are in less good condition. Finance performance in Koperasi Pegawai Republik Indonesia Kantor Urusan Agama Kabupaten Wonogiri period 2014-2017 based on solvency ratios indicate the cooperatives are in less good condition.
\end{abstract}

Keywords: Finance Performance, Earning Ratio, Activity Ratio, Liquidity Ratio, Solvency Ratio

\section{PENDAHULUAN}

Salah satu elemen penting untuk perekonomian Indonesia adalah dengan adanya koperasi. Koperasi yang didirikan, salah satu tujuannya untuk menyediakan kredit bagi masyarakat umum. Peran koperasi akan semakin baik, bila anggota dan pengurus berpartisipasi aktif dalam mengembangkan usaha. Maka aspek keuangan yang ada di koperasi harus di maksimal kan sebaik mungkin untuk meningkatkan laba maupun kualitas dari koperasi.

Zaman yang semakin berkembang ini, membuat aspek perekonomian harus menyesuaikannya. Salah satunya yang terjadi pada koperasi harus memberikan informasi yang berkaitan dengan kinerja keuangan. Informasi tersebut dapat diketahui melalui laporan keuangan yang dibuat, dengan menganalisisnya, sehingga menghasilkan informasi kinerja keuangan. Dalam pengambilan keputusan dan kebijakan koperasi yang akan dilakukan dapat didasarkan pada hasil kinerja keuangan pada periode sebelumnya. Maka pembuat laporan keuangan koperasi dituntut untuk menyusun laporan keuangan semaksimal mungkin. Hasil yang dicapai koperasi dan kondisi keuangan pada periode atau tahun tertentu dapat dilihat melalui laporan keuangan yang disusun. Pada penelitian ini analisis rasio keuangan digunakan untuk menganalisis laporan keuangan koperasi. Analisis ini diharapkan dapat memberikan informasi yang berkaitan dengan perkembangan dan kinerja koperasi. Analisis rasio keuangan yang terdiri dari tingkat rentabilitas, aktivitas, likuiditas dan solvabilitas

Koperasi Pegawai Republik Indonesia Kantor Urusan Agama Kabupaten Wonogiri yang berlokasi di Jl. Kabupaten Nomor 8, Kabupaten Wonogiri merupakan jenis koperasi simpan 
pinjam. Koperasi Pegawai Republik Indonesia Kantor Urusan Agama Kabupaten Wonogiri memberikan pelayanan yang baik, sehingga produknya banyak diminati anggota. Akan tetapi koperasi ini belum dapat dikatakan efektif dalm perkembangan usaha, karena operasional perusahaan hanya terfokus pada layanan kredit yang diberikan. Koperasi Pegawai Republik Indonesia Kantor Urusan Agama Kabupaten Wonogiri dalam menjamin kesejahteraan anggotanya tidak mudah. Hal ini terjadi karena aset yang dimiliki koperasi relatif kecil dan modal yang ada semakin berkurang, dengan banyaknya anggota yang pensiun sedangkan penambahan anggota setiap tahunnya belum pasti ada. Sehingga sampai saat ini Koperasi Pegawai Republik Indonesia Kantor Urusan Agama Kabupaten Wonogiri baru bisa mengusahakan dan mengupayakan menghimpun dana sosial dari anggota untuk disampaikan kepada anggota yang pensiun dan meninggal dunia. Dari uraian di atas penulis berpendapat layak melakukan penelitian dengan judul : Analisa Kinerja Keuangan Pada Koperasi Pegawai Republik Indonesia Kantor Urusan Agama Kabupaten Wonogiri Periode 2014-2017.

\section{LANDASAN TEORI}

Penilaian kinerja keuangan koperasi dapat melihat dari sisi keuangan maupun non keuangan. Kinerja keuangan merupakan analisis yang digunakan oleh koperasi dalam rangka memperoleh informasi hal-hal yang berkaitan dengan aspek keuangan (Fahmi, 2014: 2). Informasi tersebut dapat diketahui melalui laporan keuangan yang dibuat, dengan menganalisisnya, sehingga menghasilkan informasi kinerja keuangan. Laporan keuangan menjadi salah satu alat yang begitu penting untuk memperoleh data-data informasi yang berkaitan dengan hasil yang telah dicapai oleh koperasi (Munawir, 2016: 56). Seorang analisis membutuhkan alat ukur tertentu untuk melihat kinerja dan kondisi keuangan yang ada di koperasi. Alat analisis rasio merupakan salah satu alat yang dibutuhkan seorang analisis. Analisis keuangan adalah analisis yang dipakai oleh seorang analisis untuk melihat hubungan antara pos-pos keuangan yang ada di laporan keuangan yang terdiri dari laporan laba rugi maupun neraca (Kasmir, 2014:72). Munawir (2016: 31-33) menyatakan kinerja keuangan diukur dengan menggunakan rasio rentabilitas yang merupakan alat analisis yang digunakan untuk melihat kemampuan koperasi dalam menghasil sisa hasil usaha dalam periode tertentu, rasio aktivitas yang merupakkan alat analisis yang digunakan untuk melihat keefektifan koperasi dalam memanfaatkan dana yang ada untuk kegiatan operasional, rasio likuiditas yang merupakan alat analisis yang digunakan untuk melihat kemampuan koperasi dalam membayar hutang jangka pendek dan rasio solvabilitas yang merupakan alat analisis yang digunakan untuk melihat kemampuan koperasi dalam membayar hutang jangka panjang.

\section{METODOLOGI PENELITIAN}

Penelitian ini menggunakan penelitian kuantitatif. Tempat penelitian di Koperasi Pegawai Republik Indonesia Kantor Urusan Agama Kabupaten Wonogiri yang berlokasi di Jl. Kabupaten Nomor 8, Kabupaten Wonogiri. Dokumentasi dan studi pustaka digunakan untuk pengambilan data. Analisis rasio keuangan sebagai metode untuk menganalisis data. Rasio tersebut terdiri dari (Munawir, 2016: 31-33). 
a. Rasio rentabilitas

1) Return on Investment



\section{2) Return on Equity}

$$
\mathrm{ROE}=\frac{\mathrm{SHU}}{\text { Kekayaan Bersh }} \quad \times 100 \%
$$

b. Rasio aktivitas

1) Perputaran Aktiva

Perputaran Aktiva $=\frac{\text { Pendapatan }}{\text { Total Aktiva }} \quad$ X 100\%

c. Rasio likuditas

1) Current ratio

Current Ratio $=\frac{\text { Aktiva Lancar }}{\text { Kewajiban Lancar }} \quad$ X 100

2) Cash Ratio

$\operatorname{Cash}$ Ratio $=\frac{\text { Kas }}{\text { Kewajiban Lancar }} \quad$ X 100\%

d. Rasio Solvabilitas

1) Total debt to total assets

TDTA $=\frac{\text { Total Kewajiban }}{\text { Total Aktiva }} \quad \mathrm{x} 100 \%$

2) Debt to Equity Ratio

$D E R=\frac{\text { Total Kewajiban }}{\text { Kekayaan Bersih }} \quad \mathrm{X} 100 \%$

\section{HASIL DAN PEMBAHASAN}

\subsection{Rasio rentabilitas}

Rasio return on investment menunjukkan sisa hasil usaha yang diperoleh dari pemanfaatan total aktiva yang digunakan. Hasil perhitungan pada tahun 2014 adalah 1,96\%. Tahun 2015 mengalami peningkatan menjadi 1,97\%, adanya peningkatan sisa hasil usaha yang diperoleh dari pendapatan non operasional, adanya peningkatan kas dari tahun sebelumnya dan meningkatnya simpanan di PKP. Tahun 2016 mengalami peningkatan menjadi 2,62\% adanya peningkatan dari jumlah pendapatan operasional, adanya pendapatan dari sewa gedung kantin dan sisa hasil usaha yang diperoleh dari pendapatan non operasional. Tahun 2017 mengalami penurunan menjadi 2,04\%, meningkatnya beban usaha yang terdiri dari bunga hutang, bunga simpanan, pengadaan seragam anggota dan menurunnya sisa hasil usaha. Berdasarkan nilai rasio return on investment pada periode 2014-2017 dapat dinyatakan dalam kondisi yang kurang baik, karena nilai rasio di bawah $10 \%$. Hasil penelitian ini mendukung Adhar (2014) menyatakan kondisi kinerja keuangan koperasi ROI pada kondisi kurang baik. Koperasi harus memperbaiki kinerja keuangannya agar tidak mengalami penurunan lagi, meluncurkan produk- produk jasa sesuai dengan kebutuhan dan keinginan anggota koperasi. 
Rasio return on equity menunjukkan sisa hasil usaha yang diperoleh dari pemanfaatan kekayaan bersih. Semakin tinggi rasio ini semakin baik. Hasil perhitungan pada tahun 2014 adalah 6,47\%. Tahun 2015 mengalami penurunan menjadi 5,81\%, adanya penurunan pendapatan operasional, meningkatnya beban usaha dan beban pajak. Tahun 2016 mengalami peningkatan menjadi $6,58 \%$, adanya peningkatan dari jumlah pendapatan operasional, adanya pendapatan dari sewa gedung kantin, sisa hasil usaha yang diperoleh dari pendapatan non opersional dan meningkatkan sisa hasil usaha tahun berjalan. Tahun 2017 mengalami penurunan menjadi 4,89\%, meningkatnya beban usaha yang terdiri dari bunga hutang, bunga simpanan, pengadaan seragam anggota dan menurunnya sisa hasil usaha. Berdasarkan nilai rasio return on equity pada periode 2014-2017 dapat dinyatakan dalam kondisi yang cukup baik, karena nilai rasio 3\%-14\%. Hasil penelitian ini mendukung Adhar (2014) menyatakan kondisi kinerja keuangan koperasi berdasarkan ROE pada kondisi cukup baik. Koperasi harus memperbaiki kinerja keuangan dengan mengelola kekayaan bersih sebaik mungkin dan dapat menghasilkan keuntungan yang maksimal.

\subsection{Rasio aktivitas}

Rasio perputaran aktiva menunjukkan pendapatan yang diperoleh dari pemanfaatan total aktiva yang digunakan. Hasil perhitungan pada tahun 2014 adalah 0,18 kali. Tahun 2015 mengalami stagnan sebesar $0,18 \mathrm{kali}$, adanya penurunan pendapatan operasional dan meningkatnya uang kas sehingga perputarannya kurang efektif. Tahun 2016 mengalami peningkatan menjadi 0,2 kali, adanya peningkatan dari jumlah pendapatan operasional, adanya pendapatan dari sewa gedung kantin, sisa hasil usaha yang diperoleh dari pendapatan non opersional dan meningkat meningkatnya piutang simpan pinjam. Tahun 2017 mengalami penurunan menjadi 0,19, meningkatnya jumlah uang kas membuat perputaran aktiva kurang efektif. Berdasarkan nilai rasio perputaran aktiva pada periode 2014-2017 dinyatakan dalam kondisi yang buruk, karena nilai rasionya kurang dari 1. Hasil penelitian ini berbeda dengan Haryana, dkk (2017) menyatakan kondisi kinerja keuangan koperasi berdasarkan rasio perputaran aktiva pada kondisi cukup baik. Koperasi harus memperbaiki kinerja keuangan dengan memaksimalkan produk koperasi yang berupa kredit uang untuk dapat digunakan oleh semua anggota koperasi.

\subsection{Rasio likuiditas}

Current ratio menunjukkan kemampuan koperasi dalam membayar hutang lancar menggunakan aktiva lancar. Hasil perhitungan pada tahun 2014 adalah 323\%. Tahun 2015 mengalami penurunan menjadi $207 \%$, adanya peningkatan dari simpanan bantu modal anggota, simpanan sukarela, simpanan khusus membuat kewajiban lancarnya meningkat. Tahun 2016 mengalami penurunan menjadi 169\%, adanya penambahan hutang dari pihak ketiga, naiknya simpanan bantu modal anggota dan simpanan sukarela. Tahun 2017 mengalami penurunan menjadi $159 \%$, meningkatnya simpanan bantu modal anggota, uang kas dan simpanan sukarela. Berdasarkan nilai current ratio pada periode 2014-2017 dinyatakan dalam kondisi yang baik, karena nilai rata-rata current ratio selama 2014-2017 masih berada di atas 200\%. Hasil penelitian ini mendukung Hermina dan Ami (2016) menyatakan kondisi kinerja keuangan koperasi berdasarkan current ratio pada kondisi baik. Koperasi harus meningkatkan perputaran aktiva untuk mendapatkan sisa hasil usaha yang lebih banyak.

Cash ratio digunakan untuk melihat kemampuan koperasi dalam membayar hutang lancar menggunakan kas. Hasil perhitungan pada tahun 2014 adalah 3,58\%. Tahun 2015 mengalami peningkatan menjadi $18,52 \%$, adanya peningkatan dari uang kas, simpanan bantu modal anggota, 
simpanan sukarela dan simpanan khusus. Tahun 2016 mengalami penurunan menjadi 0,14\%, adanya penurunan uang kas yang sangat signifikan, menurunnya jumlah tabungan, adanya hutang pihak ketiga. Tahun 2017 mengalami peningkatan menjadi 0,59\%, meningkatnya uang kas, simpanan bantu modal anggota, simpanan sukarela dan penyisihan rapat anggota tahunan. Berdasarkan nilai cash ratio pada periode 2014-2017 dinyatakan dalam kondisi buruk, karena nilai rata-rata cash ratio selama 2014-2017 masih kurang dari 7\%. Hasil penelitian ini berbeda dengan Hermina dan Ami (2016) menyatakan kondisi kinerja keuangan koperasi berdasarkan cash ratio pada kondisi baik. Kondisi koperasi kurang mampu menjamin hutang lancar, maka koperasi harus meningkatkan perputaran aktiva untuk memperoleh pendapatan yang lebih baik.

\subsection{Rasio solvabilitas}

Total debt to total assets ratio mengukur besarnya dana koperasi yang didapatkan dari hutang. Hasil perhitungan pada tahun 2014 adalah 69,58\%. Tahun 2015 mengalami penurunan menjadi $66,03 \%$, adanya penurunan hutang BKE III dan BKE IV. Tahun 2016 mengalami penurunan menjadi 60,14\%, adanya penurunan tabungan, hutang BKE III dan BKE IV. Tahun 2017 mengalami penurunan menjadi 58,25\%, penurunan hutang BKE IV, simpanan primer PKP dan simpanan sekunder PKP. Berdasarkan nilai TDTA pada periode 2014-2017 dinyatakan dalam kondisi kurang baik, karena nilai rata-rata TDTA selama 20142017 masih berada diantara 61\%-80\%. Hasil penelitian ini mendukung Munir (2015) yang menyatakan kondisi kinerja keuangan koperasi berdasarkan TDTA pada kondisi kurang baik. Kondisi koperasi kurang mampu menjamin hutang, maka koperasi harus meningkatkan perputaran aktiva untuk memperoleh pendapatan yang lebih baik.

Debt to equity ratio mengukur kekayaan bersih yang digunakan untuk jaminan hutang koperasi. Hasil perhitungan pada tahun 2014 adalah 229\%. Tahun 2015 mengalami penurunan menjadi 194\%, adanya penurunan hutang BKE III dan BKE IV, penurunan sisa hasil usaha tahun berjalan. Tahun 2016 mengalami penurunan menjadi 151\%, adanya penurunan tabungan, hutang BKE III dan BKE IV. Tahun 2017 mengalami penurunan menjadi 139\%, penurunan hutang BKE IV. Berdasarkan nilai DER pada periode 2014-2017 dinyatakan dalam kondisi buruk, karena nilai rata-rata DER selama 2014-2017 masih berada di atas $80 \%$. Hasil penelitian ini mendukung Munir (2015) menyatakan kondisi kinerja keuangan koperasi berdasarkan DER dalam kondisi buruk. Koperasi harus meningkatkan perputaran aktiva untuk memperoleh pendapatan yang lebih baik

\section{KESIMPULAN DAN SARAN}

Kesimpulannya adalah:

a. Kinerja keuangan Koperasi Pegawai Republik Indonesia Kantor Urusan Agama Kabupaten Wonogiri periode 2014-2017 berdasarkan rasio rentabilitas pada kondisi kurang baik.

b. Kinerja keuangan Koperasi Pegawai Republik Indonesia Kantor Urusan Agama Kabupaten Wonogiri periode 2014-2017 berdasarkan rasio aktivitas pada kondisi buruk.

c. Kinerja keuangan Koperasi Pegawai Republik Indonesia Kantor Urusan Agama Kabupaten Wonogiri periode 2014-2017 berdasarkan rasio likuiditas pada kondisi kurang baik.

d. Kinerja keuangan Koperasi Pegawai Republik Indonesia Kantor Urusan Agama Kabupaten Wonogiri periode 2014-2017 berdasarkan rasio solvabilitas pada kondisi kurang baik. 
Saran

Penulis memberikan saran antara lain:

a. Hendaknya koperasi meningkatkan rasio rentabilitas dan aktivitas dengan mempercepat perputaran aktiva yang dimiliki koperasi untuk menghasilkan keuntungan yang maksimal.

b. Hendaknya koperasi meningkatkan rasio likuiditas dan solvabilitas meminimumkan resiko tidak tertagihnya kredit yang diberikan kepada anggota dan menginvestaikan dan yang dimiliki koperasi pada pos- pos keuangan yang menguntungkan.

\section{DAFTAR PUSTAKA}

ERLIN, R. (2016). Analisa Kinerja Keuangan Dan Kualitas Pelayanan Pada Unit Pelaksana Teknis Daerah (Uptd) Balai Metrologi Dinas Perindustrian Dan Perdagangan Propinsi Sumatera Barat (Doctoral dissertation, Universitas Andalas).

Machmud, M. (2014). Analisis Kinerja Keuangan Daerah Di Provinsi Sulawesi Utara Tahun 2007-2012. Jurnal berkala ilmiah efisiensi, 14(2).

Maith, H. A. (2013). Analisis Laporan Keuangan dalam Mengukur Kinerja Keuangan pada PT. Hanjaya Mandala Sampoerna Tbk. Jurnal EMBA: Jurnal Riset Ekonomi, Manajemen, Bisnis dan Akuntansi, 1(3).

Sijabat, M. Y. (2014). Analisis Kinerja Keuangan Serta Kemampuan Keuangan Pemerintah Daerah Dalam Pelaksanaan Otonomi Daerah (Studi Pada Dinas Pendapatan Daerah Dan Badan Pengelola Keuangan Dan Aset Daerah Kota Malang Tahun Anggaran 20082012). Jurnal administrasi publik, 2(2), 236-242.

Suryani, A. (2017). Analisa Kinerja Keuangan pada Koperasi Pegawai Negeri (Kpn) Swakerta pada Dinas Koperasi UMKM Provinsi Jambi. Jurnal Ilmiah Universitas Batanghari Jambi, 17(3), 27-37. 